\title{
Local Wisdom of Ciptagelar in Managing Environmental Sustainability
}

\author{
S. Komariah \\ Universitas Pendidikan Indonesia \\ Bandung, INDONESIA \\ sitiupi@gmail.com
}

\begin{abstract}
Indonesian society as multicultural communities have localized knowledge that is invaluable in fostering harmony with nature. As in Ciptagelar people who have a variety of localized knowledge so that their living environment is maintained. The issue that will be studied in this research is how local wisdom Ciptagelar in preserving the environment? As well as the efforts being made to improve the preservation of the environment to realize the harmony of the human environment? In this study, researchers used a descriptive research method to describe a situation or event that is associated with the implementation of local wisdom community Ciptagelar. The subject of research is the custom figures, community leaders, and community Ciptagelar. Data collection techniques in the study gained through observation, indepth interviews, the study documentation. Data analysis techniques include the reduction of the data, the presentation of data, and the withdrawal of the conclusion. The results showed Ciptagelar society has the characteristics in the form of the house, the leadership system, how to farm, how to store grain, etc. Local wisdom in preserving the environment such as the existence of customary rules that form the basis for society Ciptagelar against old forest (leuweung kolot), forest deposit (leuweung karamat) and splinter/forest openings (leuweung sampalan). In addition, there is a rule of traditional farming as ngaseuk ritual, sapang jadian pare rituals salametan nyiram pare, pare mapag beukah ritual. Mipit pare nganyaran/ngabukti, rituals and rites of seren taun.. Furthermore, there is the rule that continues to orally be passed down from generation to generation, such as planting rice only once a year, in a ceremony that must use local rice, the rice should not be beaten. Rice may not be sold, and may not be cooked on the ground directly and must use the furnace. Efforts to improve environmental protection in cooperation with the Aliansi Masyarakat Adat Nusantara (The Alliance of Indigenous Peoples of the Archipelago) a.k.a. AMAN with native peoples Ciptagelar and the Ministry of Environment conduct an interactive dialogue, environmental cadres, strengthening of environmental cadres so as to increase the role of communities as farmers and farming to the environment to the optimum and to build partnerships between native peoples, local government, the business community in addressing environmental problems.Keywords - component; formatting; style; styling; insert (key words).
\end{abstract}

Key Words: local wisdom, ciptagelar society, preserved environment.

\section{INTRODUCTION}

Indonesia has varied tribes spread from Sabang to Merauke, from Miangas to Rote Island with the dynamics of the culture of each region. So is the case in West Java precisely in Sukabumi are indigenous peoples namely Ciptagelar community. Ciptagelar has different characteristics with people outside Ciptagelar, such as setting up facilities and infrastructure, including; granary, farming systems, livelihood, economic system, culture, art, traditional institutions, which hold government and others. Ciptagelar community based on the similarity of identity and high compliance with customary norms. This is a major factor of environmental rights of indigenous villages with a variety of activities.

Ciptagelar community has local wisdom is very valuable in fostering harmony with the natural environment so that sustainability of the environment. They stay awake. This was the impetus for the selfreliance of the community Ciptagelar in managing its environment so that their food needs are met in spite of the attainment of food security because of rules to keep yields at list and share them for the common good (leuit Jimat) as well as to develop people's economy based on local wisdom in spite of Ciptagelar a set of cultural tourism and the preservation of nature in harmony.

Based on this background, the researchers want to examine about Local Wisdom Ciptagelar Society in Managing Environmental Sustainability. This study aims to describe the people in Kampung Ciptagelar with a variety of local wisdom in order to understand the existence of cultural diversity, especially the indigenous peoples Ciptagelar and examine the efforts being made to improve the preservation of the environment so as to realize the harmony of the human environment. Benefits Research theoretically, contribute to the development of sociology, in particular, with regard to rural sociology. Practically provide input to other communities in implementing the local wisdom of the environment, to give input in making policy of environmental conservation that can synergize with the local wisdom of society which harmony between man and his environment.

\section{LITERATURE REVIEW}

[1] Society is the unity of human life, which interacts according to a certain custom system that is continuous, and is bound by a sense of shared identity. Theory structural, functional and conflicts at the same examine social institutions in the community. The difference between these two theories is located on assumptions that are used by each theory. Wirawan [2] The structural functional theory assumes that: (a) the society was formed based on a consensus of residents, (b) members of communities have a shared commitment to the value, norms and culture that must be adhered to and maintained 
with, (c) the relationships between members of the public are cohesive, (d) more emphasis on solidarity between citizens, (d) reciprocity relations between citizens, the authority of the leader based on the legitimacy of the citizens of the community, and (e) the community keep order civilizing (social order) in life together. Theory of structural conflict assumes: (a) (a) the society was formed based on a conflict of interest, (b) urge members of the public change, (c) the relationships between the citizens of the community are divisive, (d) characterized the opposition more prominence in civilizing relations, (e) structural conflict became part of civilizing change in society, (f) community is also marked by a growing cultural differentiation, and $(\mathrm{g})$ the social disorder causing the community to become dynamic.

The indigenous peoples according to AMAN (the Alliance of indigenous peoples of the archipelago) at the Congress I in 1999, is: "the living communities based on the ancestral origins of the deceased on a custom region, which has sovereignty over land and natural resources, socio-cultural life that is governed by traditional law and conventional Institutions that manage the sustainability of life in society."

Indigenous peoples in conducting activities based on the customary norms which are the local wisdom of the people. [3] Localized wisdom is human intelligence, owned by certain ethnic groups gained through the experience of the community. That is, the local wisdom is the result of a specific community through their experiences and not necessarily by other communities. These values will be attached to a particular society is very strong, and it's been through a long passage of time, throughout the existence of the community. [4] The potential areas of cultural elements as local genius because it has proven its ability to survive until now. Characteristics are: competent to withstand strange cultures, can accommodate the elements of imported cultures, have the ability to integrate elements of foreign culture into the native culture, can control, and capable of giving direction to the development of culture. [5]local wisdoms are the values prevailing in a society; niali values are believed to be true and become a reference in the everyday act of local communities. [6] Local knowledge is an entity which is crucial for human dignity in the community. [7] To understand how local knowledge grows and survives need a basic of the psychological processes that build and maintain it. These processes include (1) the election of attention / selective attention is a process where a person screening the stimulus that is considered appropriate or able to touch, (2) assessment / appraisal is the process of evaluation of the stimulus which is considered to have meaning for one's life and capable of causing emotional reactions. The results of this assessment are a decision that forms the individual response by Lazarus called coping / adjustment, (3) the establishment and the categorization of concept /concept formation and Categorization.

In the daily life of everyone facing a lot of stimuli and could not follow it all. All people, objects, places, events, and activities that we experience may not be accepted and presented by our minds into a unit of information that is free. Because it is through the mechanism of psychiatric created a mental picture that is used to describe objects, places, events, and activities that we experienced then called the concept. Through concepts, we can evaluate information, take decisions and act upon these concepts. Categorization is the process of psychological concepts place grouped. A study of the formation of the test involves a person in a category classifying events, things, activities into concepts. The formation of concepts and categorization provides a way to organize the world around us into a difference of a number of specific categories. These categories are based on certain properties and objects that we sense or similar mentally (4) attributions. One common characteristic of humans is the feeling of needing to explain the reasons for the events and behaviors that occur. Attributions which became one of the characters themselves that describe mental processes to connect (create a relation) between one event and another event or one behavior with the behavior or other events, and (5) the emotion was the most important motivator of behavior that can drive us to run if fear and hit if being angry. Emotion is the important devices that read to give the idea to us how to interpret events and situations around when we see it.

\section{RESEARCH METHODS.}

This research uses the descriptive method. [7] And used to provide a clearer picture of social situations. [8] Can present a detailed overview of a particular situation, setting or events related to local wisdom Ciptagelar communities living around the Halimun Mountain National Park area in managing environmental sustainability. The research used a qualitative approach to explain thoroughly the study conducted in Ciptagelar, in particular, with regard to the localized wisdom of indigenous peoples at Kasepuhan Ciptagelar in managing their environment to remain sustainable. [9] This approach used to procedure that produces descriptive data in the form of words written or spoken of people and behaviors that can be observed. [10] There are several assumption's underlying qualitative researchers and more concerned with a process rather than outcomes or products; this approach is interested in the meaning that is how people are trying to understand life, experience, and structure their environment; Qualitative researchers are the main instrument of man rather than through inventory (inventories, questionnaires, or through the and strongly associated with fieldwork. Meaning that researchers physically engage directly with people, background (setting), place, or institution to observe or record the behavior in its natural setting; Qualitative researchers are inductive in the sense that researchers build abstractions, concepts, hypotheses, and theories.

Research subject is something, good people, things or institutions (organizations) that the nature or state of (attributes) to be investigated [11].In this research subject of the study are the ones who know the ins and outs of the values of local wisdom in kasepuhan Ciptagelar managing the environment so as to provide in-depth information to investigators about the values of local wisdom kasepuhan Ciptagelar. Informants in this study are village officials, traditional leaders, community leaders, religious leaders, youth leaders, women leaders, and community Ciptagelar. The location of the research done at Kasepuhan Ciptagelar Sukabumi. Ciptagelar which is the center of unity of the indigenous Banten Kidul are scattered now includes 3 counties namely Lebak, Bogor and Sukabumi. The location of this distinctive characteristic as an indigenous person with all their local wisdom mainly local wisdom in 
the management of their environment so that it is preserved until the preserved now. The customs of kasepuhan Ciptagelar have a characteristic that differs with the community outside Ciptagelar, such as setting infrastructure and facilities include; barns, agricultural systems, funerals, worship, livelihoods, economy, culture, the arts, Government and others. Ciptagelar community based on similarity, identity and high compliance with customary norms. Ciptagelar society was on the one hand very maintain local knowledge includes the wisdom in maintaining food security, farming wisdom, the wisdom of maintaining the environmental balance with forest arrangement, wisdom house building structure adapted to the natural environment. But Ciptagelar society is a society that is well adapted, they adjust to the changing times, especially in the development of the information through the ownership of its own radio transmitters, the construction of facilities and infrastructure that have a positive impact in the community.

Data collection techniques are ways that are implemented to gather data needed by researchers to study problems of memecahlan. Data collection techniques used in this research are the observation, in-depth interviews, and documentation study.

Observations used to uncover the facts of the symptoms and seek information in a factual, well about the description of the Ciptagelar community, as well as the sustainability of the natural environment of the community Ciptagelar. In-depth interviews are conducted to explore in-depth information from the informant with regard to research issues good Ciptagelar community, local wisdom in maintaining environmental sustainability as well as the efforts being made to improve the preservation of the environment so as to realize the harmony with the human environment.

Technical Analysis of the data that will be implemented in this study includes data reduction, data display, and conclusion or verification. Data reduction is an analytical process that is performed to sharpen, classify, directing research by focusing on things that are important to researchers who aim to gain an understanding of the data that has been collected from field notes by classifying according to the problems studied. [12] Data display is the presentation of detailed and comprehensive data by looking for patterns of relationship. Presentation of data is clear and detailed and thorough will make it easier to understand the aspects studied with regard to the values of local wisdom Ciptagelar in the management of its environment. Conclusion drawing / verification is an attempt to find meaning, meaning, explanation is done to the data that has been analyzed to look for the important things. [13] The conclusion was made in the form of a brief statement and easily understood by reference to the purpose of the study.

\section{LOCAL WISDOM IN THE PRESERVATION OF THE ENVIRONMENT.}

The life of the community of Ciptagelar very fast hold of custom/norm that has existed since long ago. Ciptagelar community, local wisdom in environmental conservation, they assume that what is Abah said (indigenous leader) is a command that must be adhered to and should not be banned. Restrict-restrictions imposed include places that are considered sacred and not to be accosted (pamali) forests, by the community it is performed according to ordered. The goal is to maintain the sustainability of the forest and biodiversity resource availability that exist within the forest.

Local wisdom in maintaining environmental sustainability with the customary rules that became the cornerstone of care for old forests (leuweung kolot) or tutupan forest, titipan forest (leuweung karamat) and forest openings/forest plots (leuweung sampalan). Forest tutupan at all should not be accessed or bullied residents for the purposes of any kind, even if just taking twigs and branches of trees. Even the community trust, if any citizen who dares to enter the tutupan forest then in effect will kabendon or kualat because it was against the rules of custom. Tutupan forests refers to a protected forest that needs to be preserved and are prohibited from destroying it. The function of the tutupan forest was not only must be preserved in order to prevent the occurrence of various natural disasters such as landslides, flooding, or drought. But bound by sanctions if there is a custom to break them. Thus, indigenous people in no way damaging to forests, forest preserve just the opposite. Titipan Forest that is the forest that can be managed and utilized for the benefit of indigenous citizens, including for the transfer of indigenous residents. Even if there are wangsit karuhun should move places. If forced to take timber, limited for the purposes of making houses or simply to the need for firewood. While the forest plots can be used for cultivation of crops that can be used for the benefit of citizens.

The Houses of Community Ciptagelar should follow the rules of the ancestors by using the shape of the State House with the House of bamboo and wood. The roof of the House comes from a palm leaf straw roofs, kiray leaves, reeds, while the floor is made of bamboo or wood boards. [14] the Middle world is the center of the universe and humans put ourselves as its Center, because that's the human habitation should be located in the Middle, not to the underworld (Earth) and the world's top (ceiling). Thus, the House should wear a pole that gives the base underneath the stone base, so that the floor of the House is not glued directly on the ground.

In making a House, they use Ki Sereh/Saninten wood and bamboo. The wall of the cubicle or woven bamboo with Wicker sasag. Bamboo is used for the House has its own philosophy, where the plans, sections of bamboo as a symbol of the age of man that has stages. Bamboo is also known as awi, empty, meaning that human beings also born into circumstances that empty to be filled with science and charity. While the use of wood to build the House of the purpose is to make their life merges with nature. Wood also called tihang hejo, meaning life just a short while.

The citizens of Kasepuhan Ciptagelar aren't using the tile roof of the House as the reason, because tile comes from the ground. They trust the people who are still alive may not be shaded by something that comes from the ground. For them, only the dead who could be sheltered by land. Moreover, the reason why they use straw roofs or kiray leaves due to dealing with one of the principles of their lives, namely kudu nyanghulu ka hukum. The principle that they have a sense that there are indigenous communities above the law, so that they uphold the custom as a source of law they are symbolized by style or 
kiray as natural ingredients. So the laws governing indigenous Ciptagelar is a natural law or the law left by their ancestors.

Ciptagelar regions are mountainous and hilly, so uneven ground contours. This affects the patterns they saw a mass spatial building in his community. The citizens of Ciptagelar mentions spatial terms paranti or umpluk wangunan. The space created to organize or classify building mass (functions), such as houses and stables, mass building of indigenous and non-indigenous, private and communal, so not mixed up. [15] Kasepuhan Ciptagelar is a hometown that have characterized sabumi, sadesa . Kampong Ciptagelar has a spatial paranti tempat beresih as well as umpluk wangunan bersih and paranti tempat kokotor or umpluk wangunan kokotor. In the settings, spatial or clean zoning occupies the front part of the pattern of the village, while zoning is dirty on the tow. Spatial orderly indirectly reflects its inhabitants who are used to living orderly.

Settlement patterns of Kampung Ciptagelar are clumped, where the pattern of placement of his House very regularly. The location of the House that one and the other are adjacent (tend to be docked). While buildings such as the ajeng, the podium, bale sesepuh, mushola, pasanggrahan and imah gede are surrounding that became a central point to cede it. The pattern of kampung influenced the circulation in the village, where its circulation patterns follow the trail There is a typical pattern of settlement Kampung Ciptagelar where on the outskirts of the village is always there smaller leuit-leuit than the house. Leuit-leuit existence itself clustered just like home.

\section{LOCAL WISDOM AND INSTITUTIONAL TRADITION.}

Kasepuhan Banten Kidul founded in 1368. Kasepuhan adat Ciptagelar is one of the kampung adat kasepuhan Banten Kidul centers his holding strong customs and traditions. Kasepuhan Ciptagelar led by indigenous leaders who are appointed on the basis of descent. Until recently, kesepuhan adat Ciptagelar led by Abah XI since the year 1368 of the kasepuhan are recorded. The name of the indigenous leaders (sesepuh girang) is Abah Ugi, who holds the position of leadership since 2007 at the age of 23, after the death of his father, known as Abah Anom.

In regulating the life of the community there are two institutions, namely the formal and non-formal institutions. Formal institution that has the function of setting that is associated with the settings of the life of a citizen of Indonesia. Whereas the non-formal institutions namely abah is also the customary by Mr. Ugi. The existence of these two institutions, existing norms and lives in the community of Ciptagelar are able to awake.

The preservation of values and norms adopted has had its own institutions. Non-formal institutions have a very important role in terms of preservation and retain existing values. The device of Kasepuhan Ciptagelar like pakakas as maintenance tooling and heritage, pamakayaan as agriculture, paninggaran as security in the field of agriculture, ke-panghuluan as religious, kadukunan as medical services, Bengkong as experts circumcision, paraji as TBA, rorokan Jero as custodian of imah gede, panahaban as environmental hygiene, ngebas as carpentry, tatabeuhan as the arts. All of the devices kasepuhan walk together in an institution called kasepuhan. Each field has a role.

Institutional customs must be adhered to by all the community i.e. saadat, sapamaksudan, sapamanggih. Saadat is the entire meaning of the citizens must unite, sapamaksudan means the whole citizens must have thought the same with the existing rules. While the sapamanggih are all the citizens should have a high sense of tolerance among citizens with one another. Kampong Gede Kesepuhan Ciptagelar is a village which has a typical custom in the location and shape of the House as well as a strong tradition which is still held by the people of his supporters. People who live in the community called Kasepuhan Ciptagelar. The term comes from the word kasepuhan with prefix ka and end an. In Sundanese, said sepuh means old. Based on this definition, the term kasepuhan, which is the home of the elderly. Kasepuhan word also refers to a class of people who are still alive and behave according to the rules of the old customs. Kasepuhan designation also shows the system model of leadership of a community or society that is based on the customs of the parents (old or stodgy). Kasepuhan means old customs or customs of ancestors. [16] kasepuhan name just a term or a designation outsider against this social group which in the past the group calling itself the offspring Pancer Pengawinan.

Abah acted as head of the Customs have an important role and influence. Structurally, the Kasepuhan custom led by Kolot Girang who accompanied by Sesepuh Induk. At the local level, there are also structural functions to run custom wheels and governance. Sesepuh Induk often become Ambassadors and mediators for interests that are outside and in, for example, pits the stodgy overtime with Abah.

In case of problems or issues of indigenous citizens, such as land dispute has occurred, it is usually first treated by Kolot lembur in the area. If it is still not finished, the problem taken to the sesepuh induk. Sesepuh induk will try to complete, if not, Abah will become the judge. Although the sequence like that, this time there is a conflict because people rarely adhere to their customary rules.. In the construction of public facilities, the Kasepuhan Ciptagelar also do it by working together. Other custom devices that prop up the course of the life of the community is Ciptagelar mabeurang (shaman), bengkong (shaman circumcision), dukun tani, dukun jiwa, paninggaran (keeping farmland), Juru doa, Juru pantun, juru sawer and some other devices to perform security functions. In addition, there are also guards or aides who accompanied the kolot lembur if on duty. There is also a poet of the Royal family in charge of playing the harp buhun while poetry.

\section{LOCAL WiSDOM, VALUES IN MUTUAL COOPERATION.}

In the life of communities Ciptagelar implemented the value of mutual cooperation of citizens is very strong, as well as their independence not to be dependent on government assistance and other parties. At the time the village Ciptagelar formed, the community worked together to build houses and village infrastructure, including big imah which is where the guests received, as well as imah Rurukan which is home Abah. Building society house fully adhering to the custom value, which should not be roofed precarious, not walled brick and 
cement, but it is the home stage of the dominant wood and bamboo, and thatched roofed chiral mixed leaves.

To support public access to other areas, roads and bridges made simple. Society does not always depend on the outside world, because it is an independent Ciptagelar Village community in building roads, bridges, and other public facilities, residents Kasepuhan Ciptagelar do with their own power by mutual cooperation. Several road and bridge construction projects that should have cost up to hundreds of millions of rupiah fully implemented on the non-indigenous Kasepuhan. Energy needs are supplied by a micro power plants by making a waterwheel. To support the implementation of education, also held independently. To support the implementation of education, also organized independently. In Ciptagelar already have school buildings. Kampong Ciptagelar also have the media information in the form of community radio. The founder of community radio, Ugi Sugriana son Abah Anom. Community radio was founded to develop custom and culture. A wide variety of arts such as Sundanese wayang golek, Sundanese classic and dog dog lojor is played. The existence of television, and handphone as a form of innovation that comes from outside can already accepted by the people of Kasepuhan Ciptagelar but with the provisions that have been agreed upon. Society is not rigid and open to new technologies that offer, because by their own indigenous leadership giving opportunity to citizens to develop into better without having to leave the customs, culture and norms existing in society.

Togetherness among people Ciptagelar looked so close, both in the public Jiwa Jero (indigenous people inside) and Jiwa Luar (outside indigenous people). Togetherness is applied in many areas of life with typical self-reliance. Ranging from rice farming, irrigation, water supply, to build up the economy, especially in achieving food security. Infrastructure development was their own doing through mutual cooperation ranging from the construction of roads, electricity, housing, to telecommunications.

\section{LOCAL WISDOM IN FOOD SECURITY AND INDEPENDENCE.}

Construction of barns (leuit) as a storage place of rice is one of the efforts made to maintain the availability of food for a year, because in Kampung Ciptagelar rice planting season is only done once a year with a view to maintaining the fertility of the soil with the kind of big melon. For the people of Sunda, leuit or granary is in fact not something foreign. Although now only in a few regions only, in the past leuit has a vital role for the Sunda; as a safe place to store grain or rice harvests both communal and individual. When the dry season arrives, the grain deposits into valuable savings. In terms of philosophy leuit contains a local knowledge that has been passed down from generation to generation through the language commonly understood to be a necessity ngeureut nendeun keur jaganing isuk (set aside for the next day) .. Leuit be a connector or a manifestation of some of the language of the teachings pitutur Sunda and this may also occur in some areas in Indonesia. A touch of tradition with shades of sacral make leuit in the unity of the indigenous residents can sustainably. There are also Leuit Si Jimat, famine barn that serves specially prepared to accommodate the dry grain, and will be issued if there are people who need it. If there is a disaster, the grain will be issued depending on the needs. Residents who run out of grain can be borrowed from other citizens or from barns famine. Therefore, the citizens of Kasepuhan Ciptagelar should not sell grain to the people outside. The reason is simple, they are living away from the urban areas if need rice, not could possibly get it right then and there. Although the ban was not even written and not a prohibition that has sanctioned if breached, all citizens of the Kasepuhan Ciptagelar stick to it. Related to this, the leuit has a typical expression of Sundanese, namely buncir leuit loba duit An expression that is associated with a State which aspired to that cannot be separated from the person's level of success.

\section{VIII.APART FROM THIS WISDOM}

People also make innovations in the form of practices as a result of learning fellow farmers, and the natural environment, including: (1) Preparation of organic fertilizers by storing manure is mixed with other organic materials (leaves, trash, trunk bananas, rice, furnace ashes, etc.) For 6 months, then used as fertilizer in rice or vegetables in the garden; (2) Model leuit cage and placed in groups. Basically leuit management as a backup storage of rice in an effort to overcome food shortages and cages are placed in groups will simplify the management and security; (3) Preservation of rice seeds by doing a good selection of rice started to be used as seed (knowledge hereditary) based on certain criteria. Type of local varieties selected are white (locan, sari kuning and jaulang) and local red (gantan and cerai) and the pattern of planting rice only once a year with a view to maintaining the level of soil fertility; (4) Utilization of rice straw as an organic fertilizer which is done by cutting rice straw after harvest, then stored in an area that occurred decay (decomposition); (5) The obligation of the heads of households save a bunch of rice in the barn together (leuit si jimat), in addition to the barn itself. With the leuit si jimat, those in need can borrow rice from the barn; (5) all stages in the farmer trying to do together (which began with the customary), in fact it is very good because with the simultaneous planting the pest can be suppressed.

\section{LOCAL WiSDOM LiVING TRUST AND RITUAL RicE.}

Rice for indigenous peoples Kasepuhan Ciptagelar not just a mere food commodities, but a symbol of life. Rice should not be bought and sold, and the cycle of cultivation farming system is controlled via the customary rules. Based philosophical Ciptagelar indigenous peoples, all the joints of indigenous life cycle based on the calendar of rice. Start harvesting paddy rice is grown up, then there are various kinds of rituals are performed. The Ciptagelar public religious system covered by the Old Sundanese public trust syncretic with Hindu and Islam. This is especially visible during traditional ceremonies were held and a living trust that they believe. The life cycle of the rice harvest to start planting in the nature trust Ciptagelar society has a set of rules and customs of the ceremony was to be held, among which: (1) Ngaseuk, planting rice was preceded by a ceremony to invoke safety and security as well as a pilgrimage to the cemetery ancestors. The ritual of ngaseuk i.e. the ceremony to meet while planting rice, pleading for safety and security to plant, celebrate the procession with entertainment activities such as wayang golek, jipeng, a mask, and pantun buhun. (2) The Sapang 
Jadian Pare, one week after the rice planting ritual held to require approval or permits to the mother (Earth) to be planted with rice, accompanied by invoking the blessing of the ancestors and the creator so rice grows well. (3) Pare,nyiram pare mapag beukah. When the rice comes out of the flower, they perform a ritual which aimed to invoke the rice in order to grow properly and to avoid pests. (4) The Sawenan, a ritual that was held after the rice grain is starting out. The ritual of sawenan i.e. The ceremony after rice out, giving the treatment of rice with the goal of keeping the rice survived and filled with good and avoid pests. (5) Mipit Pare, a ritual held at the moment will cut rice in huma dipesawahan, nor its purpose to ask for permission to the ancestors for cutting rice and also appealed to the creator provided a bountiful harvest. (6) Nganyaran or Ngabukti. Rites at a time when rice pounded and cooked for the first time, while residents wait until emak finished with its ritual; (7) Ponggokan, the tradition of the elders gathered to discuss the issue of residence based taxation of each person. Gather tradition is usually done the week before the ritual Seren year and on the implementation of Seren Taun will be discussed on this occasion. Then submit the expense Seren Taun agreed in advance and discuss Seren years to come. (8) Seren Taun. Is the culmination of indigenous peoples Ciptagelar activities in the life cycle of rice. The event is held annually as part of the tradition of honoring the ancestors and the goddess of rice Sang Hyang Pohaci (Dewi Sri), the event is held as a token of gratitude for the abundant harvests with a variety of art forms including jipeng, masks, angklung, dog dog lojor,wayang golek This event is usually attended by the indigenous people of Banten Kidul, invitations as well as the outside community kasepuhan Ciptagelar. The main one is the rice brought by paraded forward later and stored in barns, one of them in a communal granary (Leuit Si Jimat).

\section{LOCAL WISDOM IN CUSTOM CLOTHING}

How to dress for men that is wearing a peci (kopeah or Headbands) with a strong bonding while how to dress for women should wear sarong (sinjang) single bonds are strong anyway. As for the meaning of a bond that is characterizing mutual and a sense of community. While the meaning of the strong ties that are the ones holding the customary rules should be strong. For the elders there in its own custom clothing namely underwear and white headband should be black. The white color symbolizes clean while black symbolizes the mind could keep a secret.

\section{LOCAL WISDOM WITH PRACTICAL KNOWLEDGE.}

Practical knowledge gained Kasepuhan Ciptagelar community is expected to help the community in improving crop production. Agricultural extension activities that followed was not solely Kasepuhan Ciptagelar rejected by the community, but will be accepted by existing provisions. Extension activities and transfer of knowledge from the outside is also expected to improve the quality of handicraft products from Kasepuhan Ciptagelar society. Other practical knowledge gained through ancestors who taught generations. There are some practical knowledge in the communities Kasepuhan Ciptagelar as follows: (a) the treatment is done by citizens themselves, which tools and materials for medicines directly taken from nature; (b) either circumcision for boys and girls conducted by a person who has been determined and expertise in circumcision will be passed on from generation to generation; and (c) the rice granaries dimiliku by every citizen Kasepuhan Ciptagelar as a backup storage of rice so that the food crisis will not affect the state outside the community Kasepuhan Ciptagelar. In addition to the public of Kasepuhan Ciptagelar there are attempts to maintain a system of local norms and values that are always associated with the presence of natural resources sustains. Value systems embraced will still maintain the simplicity of the system of values embraced votes must be in harmony with nature, where a balanced State of nature comfortable and serene setting must also be followed by values as well as the layout behavior of the people. One of the systems the norm which is still held by the society is mutual of Kasepuhan Ciptagelar. In mutual sublime values stored where simplicity, community, as well as a very strong tolerance among its citizens.

\section{EFFORTS IN ENVIRONMENTAL CONSERVATION IN CIPTAGELAR}

Ciptagelar society greatly depends on the environment that they believe that by protecting the environment will safeguard their survival, so the use of the environment for their life done without harming the environment itself. Abah Ugi Sugriana Rakasiwi, Indigenous leader Ciptagelar highly prioritize reforestation program. Greening Program is useful to maintain the water catchment areas of greatest benefit to the interests of indigenous people. The importance of maintaining and preserving these protected forests, it has to be especially beneficial for the life and well-being. The proof, of electrical energy consumption in the traditional village utilizing river water flow through micro-hydro technology through the creation of a waterwheel. This utilization is considered not interfere with the preservation of water resources.

As part of efforts to conserve the environment function to create an environment of social harmony, the Alliance of Indigenous Peoples of the Archipelago (Aliansi Masyarakat Adat Nusantara /AMAN) along Kasepuhan Ciptagelar Society and the Ministry of Environment (MOE) held an interactive dialogue cadres environment. The event was held on July 31 to August 1, 2010 in the indigenous community Kasepuhan Cipta Gelar, Sirna Resmi, Cisolok, Sukabumi. Besides confirmation dialog will also be implemented environmental cadres.

This dialogue is an effort to find a solution how to enhance the role of farmers and farming communities to their environment to the optimum. In order for the quantity and quality of cadres Environment indigenous peoples kasepuhan increased, local initiative and selfreliance of indigenous peoples around the rise, partnerships among indigenous communities in environmental issues increases, and partnerships between indigenous peoples and the local government and the business community in environmental issues has also increased. Businesses that will be rolled out by the regional government include roadwork, which is access to the indigenous villages which are expected to add to the development in accordance with the values of the local communities. 
Traditional institutions in the social system Kasepuhan Ciptagelar have set the alignment of the public about the regularity of the relationship between humans and the natural environment and between human beings. By continuously implementing local knowledge or a system of norms and values in public life Kasepuhan Ciptagelar include: cooperation and togetherness is so big capital in the construction of facilities and infrastructure are carried out independently by the community Kasepuhan Ciptagelar; traditional ceremony seren epidemic; cropping pattern of rice using rice seeds ancestral conducted once a year with a view to maintaining soil fertility; may not sell rice to outsiders; the granaries as a food reserve that survive the economic crisis; the obligation of society to always keep the community life is relatively common, shared values, rules, personal relationships, trust, and common sense about the shared responsibility has become a social institution.

\section{XIII.EvaluATION}

Values / norms held by society Kampung Ciptagelar very beneficial because of the ban on the use of tutupan forests and titipan forest deposit the preservation of forests, soil, and water is maintained. The real existence of the prohibition to deposit and manage tutupan forest, when viewed from the aspect of forest conservation intended for forest ecosystem is maintained so as not to cause catastrophic damage erosion forests, among others remember their villages located in the hills. Besides attempting society for many innovations so that the villagers Ciptagelar open and accept new technological innovations along do not change the order of values and norms that exist in society and new technologies that provide positive values and profitable. For example innovation in agriculture, among others: Ciptagelar villagers have learned that the use of fertilizers (inorganic and organic) can increase the yield / production plants. But not all people using inorganic fertilizer with the soil reason they have relatively fertile so do not need fertilization; The public knows that the use of threshing machines and millers will be faster than the traditional way. However, these tools do not they use because the use of mortar, because the yield of rice they get is basically just for daily needs is not for sale, so that the grain pulverization process done when needed, whereas the unused grain stored in a list.

Obedience community towards traditions forming behavior patterns independently, while social ethics form a way of acting that is relatively common among his fellow citizens for example, how to be dressed and building materials used, handicrafts (model, pattern and material), to farm rice (seeds and cultivation techniques), raising goats (seedlings and technical maintenance), maintaining freshwater fish (seedlings and cultivation method), and make organic fertilizer (raw materials and composition). The daily activity patterns from a tradition to maintain harmony in order not to create competition between members of the public, further cemented with the soul of cooperativeness that is a form of mutual help and sharing among fellow.

\section{REFERENCE}

[1] Adimihardja, Kusnaka 1987. Kebudayaan dan Lingkungan. Bandung: Ilham Jaya.

[2] Amirin. 2009.Objek, subjek, dan populasi penelitian. [online]. Tersedia:http://tatangmanguny.wordpress.com/2009/04/21/subjekresponden-dan informan-penelitian/[18 Oktober 2011.

[3] Amirudin. 2005. Pengantar Metode Penelitian Hukum. Bandung: Sinar Grasindo.

[4] Ayatrohaedi. 1986.Kepribadian Budaya Bangsa (Local Genius). Jakarta: Dunia Pustaka Jaya

[5] Creswell, John W. 1994. Research Design Qualitative, Quantitative and Mixed Methods Approaches. Second Edition. London, New Delhi: International Educational and Professional Publisher

[6] Garna, Yudistira. 1984. Garna, Yudistira (1984): "Pola Kampung dan Desa, Bentuk serta Organisasi Rumah Masyarakat Sunda”. Pusat Ilmiah dan Pengembangan Regional (PIPR) Jawa Barat, Bandung.

[7] Koentjaraningrat, 2009. Pengantar Ilmu Antropologi. Jakarta: P.T Rineka Cipta

[8] Matsumoto, D. 2002. Culture, psychology, and education. In W. J. Lonner, D. L. Dinnel, S. A. Hayes, \& D. N. Sattler (Eds.), Online Readings in Psychology and Culture (Unit 2, Chapter 5), Center for Cross-Cultural Research, Western Washington University, Bellingham, Washington USA.

[9] Moleong, Lexy J. 2000. Metode Penelitian Kualitatif. Bandung: Remaja Rosdakarya

[10] Nasution. 1992. Metode Research. Bandung: Jemmars.

[11] Nuraeni, Heny Gustini dan Alfan, Muhammad. 2012. Budaya di Indonesia. Jakarta: Pustaka Setia

[12] Silalahi, Ulber. 2010. Metode Penelitian Sosial. Jakarta:Refika Aditama.

[13] Sugiyono. 2008. Metode Penelitian Kuantitatif, Kualitatif dan $R \& D$. Bandung: Alfabeta.

[14] Wirawan. 2012. Evaluasi Kinerja Sumber Daya Manusia, Teori Aplikasi dan Penelitian. Jakarta: Salemba Empat. 